\title{
ANALISIS PENGEMBANGAN WILAYAH OBJEK WISATA SEGITIGA DANAU DI KABUPATEN LUMAJANG
}

\author{
Yulia Dwi Firdiana \\ Universitas Kanjuruhan Malang \\ Email: yuliadwifir@gmail.com
}

\begin{abstract}
Abstrak
Objek wisata Segitiga Danau yang terletak di Kecamatan Klakah dan Ranuyoso, Kabupaten Lumajang. Objek wisata Segitiga Danau merupakan objek wisata dengan latar belakang kondisi alam yang sangat indah yang terletak di lereng pegunungan Lemongan. Objek wisata ini mempunyai daya tarik tersendiri yang mampu menarik wisatawan untuk berkunjung. Tujuan dari diadakannya penelitian ini adalah (1) Mengetahui faktor-faktor geografi yang mendukung dalam pengembangan objek wisata Segitiga Danau; (2) mendefinisikan Mengetahui usaha-usaha yang dilakukan oleh pemerintah Kabupaten Lumajang dalam pengembangan objek wisata Segitiga Danau; (3) Mengidentifikasi potensi-potensi alam yang dapat dikembangkan sebagai daya tarik tambahan di dalam kawasan objek wisata Segitiga Danau; dan (4) Untuk mengetahui pengaruh pengembangan obyek wisata Segitiga Danau terhadap kesejahteraan warga sekitar obyek wisata. Sedangkan manfaat dari diadakannya penelitian ini adalah (1) Penelitian ini diharapkan dapat memberikan masukan bagi pemerintah daerah, khususnya bagi Dinas Pariwisata dalam mengembangkan objek pariwisata dan menentukan kebijaksanaan-kebijaksanaan yang menyangkut kepariwisataan dengan tetap memperhatikan faktor-faktor geografi; (2) Hasil penelitian ini diharapkan dapat memberikan sumbangan bagi pengembangan ilmu geografi, khususnya untuk pengembangan geografi kepariwisataan.
\end{abstract}

Kata Kunci: Pariwisata, pengembangan pariwisata

\section{PENDAHULUAN}

Dalam rangka mencapai tujuan pengembangan pariwisata, pembangunan pariwisata harus diarahkan pada pemanfaatan sumber daya alam. Semakin besar sumber daya alam yang dimiliki suatu negara, maka semakin besar pula harapan untuk mencapai tujuan pembangunan dan pengembangan pariwisata.

Tujuan pengembangan pariwisata akan berhasil dengan optimal bila ditunjang oleh potensi daerah yang berupa objek wisata alam maupun objek wisata buatan manusia. Yoeti (1996:5) mengatakan bahwa pembangunan dan pengembangan daerah menjadi daerah tujuan wisata tergantung dari daya tarik itu sendiri yang dapat berupa keindahan alam, tempat bersejarah, tata cara hidup bermasyarakat maupun upacara keagamaan.

Dari uraian tersebut, sektor kepariwisataan perlu mendapat penanganan yang serius karena kepariwisataan merupakan kegiatan lintas sektoral dan lintas wilayah yang saling terkait, diantaranya dengan sektor industri, perdagangan, pertanian, perhubungan, kebudayaan, sosialekonomi, politik, keamanan serta lingkungan.

Disamping perlunya pula peningkatan promosi dan pemasaran pariwisata serta peningkatan pendidikan dan pelatihan pariwisata, penyediaan sarana-prasarana mutu dan kelancaran pelayanan penyelenggaraan pariwisata. Pengembangan pariwisata adalah upaya untuk meningkatkan sumber daya yang 
dimiliki oleh suatu objek wisata dengan cara melakukan pembangunan dari berbagai unsur, baik unsur alam atau buatan manusia dari sistem pembangunan pariwisata sehinggga meningkatkan produktifitas objek wisata. Dalam hal ini yang dimaksud dengan produktifitas objek wisata berupa meningkatnya pendapatan daerah yang diperoleh dari kunjungan wisatawan yang masuk. Pengembangan pariwisata dalam penelitian ini adalah tentang upaya-upaya yang dilakukan oleh pemerintah dalam hal ini pemerintah Kabupaten Lumajang untuk mengembangkan pariwisata.

Sebagai salah satu daerah tujuan wisata, Kabupaten Lumajang memiliki aset wisata yang cukup beragam yang dapat memenuhi segala kebutuhan kepariwisataan jika aset tersebut dimanfaatkan secara optimal. Salah satu potensi wisata yang belum berkembang dan merupakan objek wisata yang potensial untuk dikunjungi adalah objek wisata Segitiga Danau yang terletak di Kecamatan Klakah dan Ranuyoso, Kabupaten Lumajang.

\section{METODE PENELITIAN}

Penelitian ini menggunakan rancangan penelitian kualitatif. Rancangan penelitian kualitatif adalah suatu proses penelitian dan pemahaman yang berdasarkan pada metodologi yang menyelidiki suatu fenomena sosial dan masalah manusia. Ruang lingkup dalam penelitian ini ialah berada di wilayah administrasi Kabupaten Lumajang, dan objek yang hendak diteliti ialah objek wisata Segitiga Danau (Ranu Klakah, Ranu Pakis, dan Ranu Bedali) Kabupaten Lumajang, pengunjung serta masyarakat sekitar.
Variabel penelitian berkaitan dengan faktor-faktor geografi yang berkaitan dengan pengembangan objek wisata Segitiga Danau di Kecamatan Ranuyoso Kabupaten Lumajang, sebagai berikut: 1) faktor alam meliputi lokasi, keadaan iklim, keadaan geologi, keadaan morfologi, kondisi tanah, kondisi air, floradan fauna; dan 2) faktor sosial dan pengembang meliputi keadaan penduduk, daya tarik, infrastruktur, fasilitas pelayanan, akomodasi, permodalan, pengelolaan yang ada di objek wisata Segitiga Danau.

Dalam penelitian ini alat pengumpulan data yang digunakan yaitu dokumentasi, observasi, angket,dan wawancara Setelah melakukan penggalian data di lapangan selanjutnya dilakukan analisis data. Dalam analisis data penulis menggunakan analisis deskriptif kualitatif dan analisis SWOT.

\section{HASIL DAN PEMBAHASAN}

\section{Faktor Geografis Yang Mendukung Potensi Wisata Segitiga Danau}

\section{a. Lokasi/Letak}

Segitiga Danau terletak di Desa Ranubedali, Tegalrandu dan Ranupakis Kecamatan Ranuyoso dan Kecamatan Klakah. Jarak dari Kabupaten/kota Lumajang sekitar $20 \mathrm{~km}$. Segitiga Danau ini terletak pada ketinggian 900 mdpl. Kondisi jalan menuju lokasi objek wisata ini cukup baik karena sudah aspal, dan lebar jalan sekitar 3 meter.

\section{b. Kondisi Morfologi}

Segitiga Danau merupakan tempat wisata yang sangat indah dan alami. Pepohonan yang ada disekitar objek wisata menambah kealamian objek wisata ini. 
c. Jenis Tumbuhan dan Hewan

Tumbuhan yang terdapat di area Segitiga Danau ini adalah pohon pinus. Dan hewan yang ada di dalam objek wisata ini adalah monyet. Selain itu juga banyak terdapat jenis burungburung liar penghuni hutan.

d. Penduduk

Kecamatan Ranuyoso dan Kecamatan Klakah merupakan wilayah dari Kabupaten Lumajang yang berada di dataran tinggi sehingga mayoritas penduduk yang berada di Kecamatan ini berprofesi sebagai petani. Begitupun dengan penduduk di sekitar objek wisata, mereka juga berprofesi sebagai petani tetapi ada juga yang menjadi pembudidaya ikan di lokasi objek wisata.

\section{Potensi Yang Dapat Dikembangkan Dalam Objek Wisata Segitiga Danau}

Berdasarkan hasil observasi yang telah dilakukan, Segitiga Danau memiliki banyak potensi tambahan yang dapat dikembangkan juga sebagai daya tarik tambahan. Misalnya saja, air terjun dan kolam pemandian yang letaknya tidak begitu jauh dari Segitiga Danau. Serta adanya sebuah sarana olahraga tenis, futsal dan olahraga air.

a. Usaha Yang Dilakukan Dalam Pengembangan Objek Wisata Segitiga Danau

Pengembangan pariwisata

Kabupaten Lumajang tidak saja hanya melihat dari faktor internal objek dan daya tarik wisata, tetapi juga harus terkait dengan faktor eksternal yang didukung melalui:

1) Peningkatan pendidikan dan pelatihan kepariwisataan.

2) Promosi dan pemasaran secara profesional.

3) Meningkatkan sadar wisata berdasarkan sapta pesona melalui penyuluhan terhadap masyarakat, kelompok-kelompok seni, dan kerajinan industri.

4) Meningkatkan kemampuan untuk menjamin mutu kepariwisataan.

5) Kelancaran pelayanan pariwisata serta penyelenggaraan kegiatan kepariwisataan di Kabupaten Lumajang.

b. Kontribusi Obyek Wisata Segitiga Danau Di Kabupaten Lumajang Terhadap Warga Sekitar Obyek Wisata

Kontribusi yang diberikan obyek wisata Segitiga Danau terhadap kesejahteraan dan perekonomian masyarakat cukup signifikan, dan memberikan dampak positif. Hal ini dibuktikan dengan pedagang kaki lima yang bersal dari masyarakat sekitar obyek wisata dan juga masyarakat sekitar membuka rumah makan atau warung, sehingga memberikan pendapatan tambahan. 
c. Analisis SWOT

\begin{tabular}{|c|c|c|}
\hline EFE & $\begin{array}{c}\text { Strength }(\mathbf{S}) \\
\text { Faktor Kekuatan }\end{array}$ & $\begin{array}{c}\text { Weakness }(\mathbf{W}) \\
\text { Faktor Kelemahan }\end{array}$ \\
\hline & $\begin{array}{c}\text { Strategi (SO) Gunakan } \\
\text { kekuatan untuk memanfaatkan } \\
\text { peluang }\end{array}$ & $\begin{array}{c}\text { Strategi (WO) } \\
\text { Atasi kelemahan dengan } \\
\text { memanfaatkan peluang }\end{array}$ \\
\hline $\begin{array}{l}\text { Opportunities } \\
\text { (O) } \\
\text { Faktor } \\
\text { Peluang }\end{array}$ & $\begin{array}{l}\text { - Dengan aksesibilitas } \\
\text { mudah dijangkau yang berupa } \\
\text { aspal dapat meningkatkan } \\
\text { pengunjung } \\
\text { • Wisata ini merupakan } \\
\text { wisata alam yang menyajikan } \\
\text { rangkaian tiga danau dengan } \\
\text { keunggulan masing-masing } \\
\text { danau } \\
\text { • Dengan tiket yang murah } \\
\text { dapat meningkatkan wisatawan, } \\
\text { terbukti dengan data wisatawan } \\
\text { tiga tahun terahir dari tahun } \\
\text { 2010-2012 hingga sekarang } \\
\text { • Lokasi Segitiga Danau } \\
\text { Lumajang yang berada di sekitar } \\
\text { jalan provinsi bisa menarik } \\
\text { wisatawan untuk berkunjung } \\
\text { • } \quad \text { Merupakan salah satu } \\
\text { rangkaian objek wisata danau } \\
\text { dan gunung yang ada di } \\
\text { Lumajang }\end{array}$ & $\begin{array}{l}\text { - Meningkatkan manajemen } \\
\text { kontrol terhadap sarana prasarana dan } \\
\text { promosi wisata } \\
\text { • Membuat souvenir atau oleh- } \\
\text { oleh yang merupakan ciri khas wisata } \\
\text { Segitiga Danau Lumajang, misalnya; } \\
\text { tas anyaman, batik dan sebagainya } \\
\text { - Koordinasi antara pengelola } \\
\text { dan pemerintah daerah untuk } \\
\text { mengatasi masalah yang muncul } \\
\text { - lahan kosong yang terdapat di } \\
\text { sekitar Danau supaya di jadikan } \\
\text { tempat para pedagang supaya para } \\
\text { pedagang tidak berjualan sembarangan } \\
\text { di depan lokasi Wisata Danau }\end{array}$ \\
\hline \multirow[b]{2}{*}{$\begin{array}{l}\text { Threats }(\mathbf{T}) \\
\text { Faktor } \\
\text { Ancaman }\end{array}$} & $\begin{array}{c}\text { Strategi (ST) } \\
\text { Gunakan kekuatan untuk } \\
\text { mengatasi ancaman }\end{array}$ & $\begin{array}{c}\text { Strategi }(\mathbf{W T}) \\
\text { Meminimalkan kelemahan dan } \\
\text { menghindari ancaman }\end{array}$ \\
\hline & $\begin{array}{l}\text { - Mengadakan promosi ke } \\
\text { daerah lain dengan kekuatan } \\
\text { aksesibilitas sangat mudah } \\
\text { dijangkau dan keindahan } \\
\text { eksotisme Danau dan Gunung } \\
\text { Lemongan } \\
\text { - Dengan meningkatnya } \\
\text { pengunjung, masyarakat akan } \\
\text { antusias untuk memanfaatkan } \\
\text { wisata tersebut }\end{array}$ & $\begin{array}{l}\text { - Mengadakan koordinasi antara } \\
\text { pemerintah daerah dan pengelola } \\
\text { (manajemen control) dalam mengatasi } \\
\text { kelemahan bersamaan dengan ancanan } \\
\text { - Dukungan pengelola dengan } \\
\text { memberikan solusi masalah mengenai } \\
\text { kurangnya sarana prasarana } \\
\text { - Mendorong masyarakat untuk } \\
\text { memanfaatkan wisata Segitiga Danau }\end{array}$ \\
\hline
\end{tabular}


Berdasarkan analisis SWOT di atas, dapat disimpulkan bahwa adanya Objek Wisata Segitiga Danau di Kecamatan Ranuyoso dan Kecamatan Klakah ini mempunyai pengaruh positif maupun negatif yang ditimbulkan. Adapun pengaruh pengaruh positif dari keberadaan Objek Wisata Segitiga Danau yaitu: 1) semakin luasnya kesempatan usaha yang dilakukan para pedagang dengan membuka usahausaha dagang, 2) membuka lapangan pekerjaan terhadap masyarakat disekitar lokasi objek wisata. Sedangkan pengaruh negatif yang ditimbulkan adalah, 1) meningkatnya harga di daerah wisata, 2) adanya persaingan, pertentangan atau pertikaian antar pedagang, 3) adanya pencemaran dan kerusakan lingkungan.

\section{KESIMPULAN}

Dari hasil penelitian dapat diambil kesimpulan, yaitu:

a. Faktor-faktor geografis yang mendukung dalam pengembangan obyek wisata Segitiga Danau antara lain: (1) lokasi, dengan jarak yang jauh dari pusat Kabupaten Lumajang sangat mendukung sebagai kawasan obyek wisata alam, karena kelestarian obyek wisata alam tersebut tidak terganggu oleh aktivitas polusi di daerah perkotaan; (2) iklim, obyek wisata alam Segitiga Danau yang terletak di lereng Gunung Lemongan menjadikan kawasan tersebut mempunyai iklim yang sejuk dengan suhu. Hal tersebut sangat mendukung dalam proses pengembangan pariwisata; (3) kondisi hidrologi, kondisi hidrologi di daerah penelitian sangat mendukung dalam upaya pengembangan pariwisata karena pada daerah penelitian terdapat beberapa sumber mata air yang telah dimanfaatkan untuk air bersih dan irigasi;. (4) jenis tanah, jenis tanah yang ada di daerah penelitian adalah tanah alluvial, regosol, andosol, mediteran, dan latosol. Jenis tanah ini sangat baik untuk perkembangan tumbuhan di kawasan tersebut, sehingga faktor jenis tanah sangat mendukung dalam upaya pengembangan pariwisata; (5) aktifvitas penduduk, kondisi pedesaan yang identik dengan pertanian sangat mendukung sebagai daerah wisata dengan latar belakang alam yang indah; (6) flora dan fauna, terdapat flora dan fauna yang khas dari daerah tersebut.

Sedangkan faktor-faktor geografis yang kurang mendukung dalam pengembangan obyek wisata Segitiga Danau antara lain: (1) kemiringan lereng, dengan kemiringan lereng yang terjal akan menjadi kendala untuk mendirikan bangunan karena daerah tersebut rawan bencana tanah longsor; (2) tingkat pendidikan penduduk, pada daerah penelitian dapat diketahui tingkat pendidikan penduduknya masih tergolong rendah. Hal ini akan mempengaruhi cara pandang masyarakat dalam menanggapi suatu fenomena atau permasalahan yang ada.

b. Usaha-usaha yang dilakukan pemerintah Kabupaten Lumajang dalam pengembangan kawasan obyek wisata Segitiga Danau antara lain: (1) pada kawasan obyek wisata alam harus dilestarikan sehingga dapat menunjang kehidupan flora dan fauna yang hidup di tempat tersebut; (2) obyek wisata alam memiliki nilai wisata dan penelitian atau pendidikan, sehingga diperlukan pengembangan jalur wisata yang menjadikan lokasi obyek wisata alam sebagai salah satu obyek wisata yang menarik dan menjadi salah satu tujuan atau obyek penelitian dan pendidikan; (3) menambah dan membenahi fasilitas penunjang atau sarana yang ada di obyek wisata; (4) meningkatkan 
kegiatan promosi wisata; (5) melakukan kerja sama dengan dinas terkait; (6) melakukan sosialisasi terhadap masyarakat sekitar agar mempunyai rasa peduli terhadap lingkungan.; (7) Kawasan obyek wisata Segitiga Danau yang masih sangat alami dengan hutan pinus yang cukup luas sangat potensial jika pada kawasan ini dibangun taman marga satwa, selain dapat menambah daya tarik wisata, keberadaan taman marga satwa juga dapat dijadikan sebagai tempat untuk melindungi hewan-hewan langka yang menjadi ciri khas daerah setempat agar tidak punah.

c. Segitiga Danau memiliki banyak potensi tambahan yang dapat dikembangkan juga sebagai daya tarik tambahan. Misalnya saja, air terjun dan kolam pemandian yang letaknya di Danau Bedali. Adanya sebuah sarana olahraga tenis, futsal, olahraga air, hotel dan aula yang ada di Danau Klakah. Serta keramba ikan yang ada di Danau Pakis.

d. Kontribusi yang diberikan obyek wisata Segitiga Danau terhadap kesejahteraan dan perekonomian masyarakat cukup signifikan, dan memberikan dampak positif. Hal ini dibuktikan dengan pedagang kaki lima yang bersal dari masyarakat sekitar obyek wisata dan juga masyarakat sekitar membuka rumah makan atau warung, sehingga memberikan pendapatan tambahan.

\section{DAFTAR RUJUKAN}

Arikunto. 1998 Prosedur Penelitian

Suatu Pendekatan Praktek. Jakarta: Rineka Cipta.

Bintarto, R. dan Hadisumarno, S. 1991. Metode Analisis Geografi. Jakarta: LP3ES.

Daldjoeni, N. 2004. Pedesaan Lingkungan Dan Pembangunan. Bandung: Alumni.

Fadeli, Chafid. 2001. Pariwisata Indonesia. Yogyakarta.

Karyono, A. Hari. 1997. Kepariwisataan. Jakarta: Gramedia.

Pendit, Nyoman S. 2006. Ilmu Pariwisata Sebuah Pengantar Perdana. Jakarta: Pradnya Paramita.

Spillane, James S. 1994. Pariwisata Indonesia Sejarah dan Prospeknya. Yogyakarta: Andi.

Suharyono. 1994. Pengantar Filsafat Geografi. Depdikbud.

Undang-undang No. 9 Tahun 1990 Tentang Kepariwisataan.

Wiwoho. 1990. Pariwisata, Citra dan Manfaatnya. Jakarta : PT. Bina Rena Pariwara.

Yoeti, Oka A. 1996. Pemasaran Wisata Melestarikan Budaya Yang Nyaris Punah. Bandung: Angkasa.

Yoeti, Oka A. 2007. Perencanaan dan Pengembangan Pariwisata. Jakarta : PT. Pradnya Pramita. 